\title{
The Influence of Professional Competence, Work Motivation \& Learning Motivation on the Competency Test Results of Social Studies Teachers
}

\author{
Aminuyati' ${ }^{1}$; Achmadi ${ }^{2}$; Okiana $^{3}$ \\ ${ }^{1,2,3}$ Department of Education-Social Science, Universitas Tanjungpura, Pontianak, Indonesia \\ Corresponding Author: Achmadi
}

\begin{abstract}
The teacher plays a role in students' cognitive, affective and psychomotor maturation through the teaching and learning process by transferring knowledge, personality and skills to students. The achievement of student learning outcomes is inseparable from professional competence, work motivation, and learning motivation possessed by the teacher in the learning process. Looking at this, it is necessary to design an instrument to measure professional competence, work motivation, learning motivation on the results of social studies teacher competency tests at junior high school level in public schools in Pontianak City. This study uses a quantitative approach, with a population of 119 social studies teachers, a total sample of 82 social studies teachers with proportionate stratified random sampling technique, which is found in 28 junior high schools in 7 sub-districts of Pontianak. Problem solving uses Multiple Linear Regression with a pathway hypothesis model (beta) pathway in Multiple Linear Regression. The results of the study show that: (1) professional competence has a direct positive effect on the results of the social studies teacher competency test; (2) work motivation has a direct positive effect on the results of the social studies teacher competency test; (3) learning motivation has a direct positive effect on social studies teacher competency test results; \& (4) professional competence, work motivation, learning motivation simultaneously have a direct positive effect on the results of the competency test of social studies teachers in Pontianak City.
\end{abstract}

Keywords: Professional Competence, Work Motivation, Learning Motivation, Competency Test Results

\section{INTRODUCTION}

Education plays an important role to improve the quality of life of the nation, because through education can create quality human resources and noble character, preparing future generations and the success of human resources into a better future. Because through education according to the level everyone will get change and maturity knowledge, skills and skills. In line with the Republic of Indonesia Law Number 20 of 2003 concerning the National Education System which "functions to develop the ability and form dignified character and civilization in the framework of educating the life of the nation, aims to develop the potential of students to be faithful and devoted to God Almighty, noble, healthy, knowledgeable, capable, creative, independent, and a democratic and responsible citizen. [1]

In order to anticipate the role of creating quality human resources and preparing quality human capital, of course the world of education must make changes that lead to the demands of globalization. As with the competency of a teacher to support the transfer of knowledge in the learning process. So that students not only know the concepts and theories but must be able to recognize various social environmental events and problems, so as to solve social 
problems that occur in their environment. In this case students are required to be more active to record social events that occur in the environment, both at the level of individuals or households, communities and countries, so that they can benefit from a better life. in short, the results of the education process are required to produce the necessary human resources in an era of global competition, and truly become a high value "human capital" as well as what Becker (1993) writes is "an important investment in creating human capital". ${ }^{[2]}$ In line with the opinion of Tilaar (2000) "relating to this matter, the main points of a new paradigm in national education are needed, which are aimed at developing behavior that addresses internal and global challenges. ${ }^{[3]}$

Student learning outcomes can not be separated from the professional competence of teachers in the learning process. To transfer knowledge that is reflected in the curriculum. In line with Gilbert, Aminuyati (2016) cited that the curriculum must be supported by a positive, affective and psychomotor domain in the hope that students can get the maximum knowledge, so that there is a change in the maturity of students after learning. [4] Students have the competence of knowledge, personality and skills. To support maturity, surely the teacher must have pedagogical competence, professional competence, personality competence and social competence.

Motivation of teacher work is an activity that is carried out consciously because there is an impulse that comes from within or comes from outside someone, a motivational teacher who is high and positive will work with enthusiasm, creative, innovative, full of ideas, initiative and have a sense high self confidence. Conversely, if the teacher's work motivation is low and negative, then people appear weak, lazy, passive, less creative, lack initiative and tend to avoid work because they lack high self-confidence. Jones, et al. (2008) said that work motivation is an energetic set of strengths originating from both inside and outside the individual for work needs in the form of direction, intensity, duration of work. ${ }^{[5]}$ While Pinder (2008) explain work motivation as an activity in the face of events in the world of work, career and leadership of people in the world of work. ${ }^{[6]}$ Whereas Murray, Locke, Latham in Pinder (2008) say "perseverance is the main element of work motivation". [6] According to Herbert and Gullet cited by Maslow (2006) explaining work motivation is "the needs and desires of someone to work supported by internal factors (physical needs, security needs, social needs, appreciation needs and self-implementation needs) and external factors (salary / wages, working conditions, work environment, work facilities, responsibilities and selfdevelopment) ". ${ }^{[7]}$

Motivation is an encouragement or mental strength in the form of desire, attention, friendship and ideals as a driver to carry out activities in achieving goals and meeting needs. In the process of teaching and learning motivation is needed by the teacher / student, then the teacher / student who does not have the motivation to learn will not be possible to do learning activities. Therefore, the principal has an important role in giving attention to the teacher. Likewise, teachers play an important role in giving attention to students. Learning motivation is a psychological process in a person to carry out learning activities so that there is a change in understanding and insight about knowledge, personality and skills. Student motivation is an internal and external encouragement to students who are learning to demand knowledge and behavior changes and improve skills supported by several indicators (Hamzah B. Uno, 2014). [8]

Teacher competency testing is an activity carried out to evaluate, assess and measure the level of basic competency of teachers in the field of study and pedagogics in the teacher's content domain, in order to carry out professional duties and responsibilities as a teacher. Teacher 
competency testing is carried out for study teachers who are certified educators and subject teachers who do not yet have an educator certificate. The competency tested is the integration of pedagogic competencies into the learning process of the field of study in the classroom. The goal, including "In an effort to conduct teacher performance assessments". The teacher is a very important person in educating the life of the nation's children. Because teachers play a role in educating the lives of the nation's children, the government gives special attention to teachers by implementing teacher competency tests that aim to strive to improve the quality of education for the life of the nation's children. It was even announced by the president of the Republic of Indonesia on December 4, 2004 which strengthened the role of teachers in the implementation of education. In line with the Republic of Indonesia Law number 14 of 2005 concerning teachers and lecturers. The development and development of the teaching profession is carried out for teachers who already have an educator certificate as well as for teachers who do not yet have an educator certificate, which is carried out sustainably as the actualization of the teaching profession. The implementation of the competency test has been carried out simultaneously throughout Indonesia starting in 2015, in 2016. ${ }^{\text {[9] }}$

In Pontianak City in 7 Subdistricts there were 28 Junior High School with 119 Social Studies teachers, most of them had passed Teacher Certification. In 2015 the teacher competency test was carried out by the Pontianak City Education Office with a competency standard of 60, it turned out that the results of the competency test were still not optimal as expected, because there were still scores of teachers below the specified standard, 60. 2016 teachers by the Pontianak City Education Office with 80 competency standards, it turns out that the results of the competency test are still not maximally as expected, because there are still scores of teachers below the specified standard, which is 80. Such conditions, then in May 2017, the City Education Office carried out assistance to improve the professional competence of public / private school teachers at the junior high school level in collaboration with the Teacher Training and Education Faculty of Tanjungpura University Pontianak as a mentoring instructor. Because there are still many teachers who have not maximized the results of their competency test, if this is not addressed, it will hamper the process of improving quality in learning so that equitable development in the field of education to produce a better future generation will not be achieved. For this reason, the Pontianak City Government, through the Office of Education, needs to make improvements or steps so that teachers can feel justice, prosperity and equitable development in the field of education.

Looking at the above problems, it is necessary to design an instrument to measure professional competence, work motivation, learning motivation towards the results of teacher competency tests. Through this research, it is expected that the teacher competency test results will be clearly known, so that it can be a guideline for policy makers related to teacher competency mapping in Pontianak City.

\section{METHOD}

This study uses a quantitative approach, with a population of 119 social studies teachers, a sample of 82 social studies teachers with a proportionate stratified random sampling technique, which is found in 28 junior high schools spread across 7 Pontianak City Districts. Problem solving using Multiple Linear Regression with the hypothetical path coefficient (beta) model in Multiple Linear Regression.

\section{RESULT AND DISCUSSION}

The following is presented the results of statistical calculations: 
Aminuyati et.al. The influence of professional competence, work motivation \& learning motivation on the competency test results of social studies teachers.

Direct Effect of X1 on Y

\begin{tabular}{|c|c|c|c|c|c|c|}
\hline \multicolumn{7}{|c|}{ Coefficients $^{\mathrm{a}}$} \\
\hline \multirow{2}{*}{\multicolumn{2}{|c|}{ Model }} & Unstanda & d Coefficients & Std Co. & $t$ & Sig. \\
\hline & & B & Std. Error & Beta & & \\
\hline \multirow[t]{2}{*}{1} & (Cons) & 76.492 & 13.571 & & 5.636 & .000 \\
\hline & $\mathrm{X} 1$ & .331 & .106 & .330 & 3.131 & .002 \\
\hline
\end{tabular}

\section{Direct Effect of X2 on Y}

\begin{tabular}{|c|c|c|c|c|c|c|}
\hline \multicolumn{7}{|c|}{ Coefficients $^{\mathrm{a}}$} \\
\hline \multirow{2}{*}{\multicolumn{2}{|c|}{ Model }} & \multicolumn{2}{|c|}{ Unstandardized Coefficients } & \multirow{2}{*}{$\begin{array}{c}\text { Std Co. } \\
\text { Beta }\end{array}$} & \multirow{3}{*}{$\begin{array}{c}\mathbf{t} \\
15.079\end{array}$} & \multirow{3}{*}{$\begin{array}{l}\text { Sig. } \\
.000\end{array}$} \\
\hline & & B & Std. Error & & & \\
\hline 1 & (Cons) & 97.374 & 6.458 & & & \\
\hline & $\mathrm{X} 2$ & .162 & .048 & .350 & 3.347 & .001 \\
\hline
\end{tabular}

\section{Direct Effect of X3 on Y}

\begin{tabular}{|c|c|c|c|c|c|c|}
\hline \multicolumn{7}{|c|}{ Coefficients $^{\mathrm{a}}$} \\
\hline \multirow{2}{*}{\multicolumn{2}{|c|}{ Model }} & Unstandar & d Coefficients & Std Co. & $\mathbf{t}$ & Sig. \\
\hline & & B & Std. Error & Beta & & \\
\hline \multirow[t]{2}{*}{1} & (Cons) & 90.940 & 9.267 & & 9.814 & .000 \\
\hline & $\mathrm{X} 3$ & 239 & .079 & 320 & 3.026 & .003 \\
\hline
\end{tabular}

Simultaneous Direct Effect of X1, X2, \& X3 on Y

\begin{tabular}{|c|c|c|c|c|c|c|}
\hline \multicolumn{7}{|c|}{ Coefficients $^{\mathrm{a}}$} \\
\hline \multirow{2}{*}{\multicolumn{2}{|c|}{ Model }} & \multicolumn{2}{|c|}{ Unstandardized Coefficients } & \multirow{2}{*}{$\begin{array}{c}\text { Std Co. } \\
\text { Beta } \\
\end{array}$} & \multirow[t]{2}{*}{$\mathbf{t}$} & \multirow[t]{2}{*}{ Sig. } \\
\hline & & B & Std. Error & & & \\
\hline \multirow[t]{4}{*}{1} & (Cons) & 54.354 & 14.187 & & 3.831 & .000 \\
\hline & $\mathrm{X} 1$ & .221 & .104 & .220 & 2.125 & .037 \\
\hline & $\mathrm{X} 2$ & .127 & .047 & .276 & 2.732 & .008 \\
\hline & X3 & .164 & .077 & .220 & 2.141 & .035 \\
\hline
\end{tabular}

\section{Direct Effect of Teacher Professional Competence (X1) on Teacher Competency Test Results (Y)}

The empirical results found that the professional competence of teachers had a direct positive effect on the results of the competency test for social studies teachers at Pontianak City Junior High School. Professional competencies possessed by a teacher are needed to support the transfer of knowledge in the learning process. So that students not only know concepts and theories but must be able to recognize various events and problems in the social environment, so they are able to solve social problems that occur in their environment. In this case students are required to be more active in recording social events that occur in the environment, both at the level of individuals or households, communities and countries, so that they can benefit from a better life, in short, the results of the education process are required to produce human resources needed in the era of global competition, and truly become a high value "human capital". Education is an important investment in creating human capital (Becker, 1993). ${ }^{[10]}$ Education that can build human capital requires the main points of a new paradigm in National Education, including being directed at developing behavior that addresses internal and global challenges (Tilaar, 2000). ${ }^{\text {[3] }}$ In other words, in the era of global competence demands the availability of human capital that can bring a nation be a winner, and get better. To improve quality, especially students, it needs to be supported by parents, teachers to motivate their students and be supported by a conducive learning climate. Because the learning atmosphere developed by the teacher has a very big influence on the success of the students' enthusiasm for school.

Professional competence is the main component of the teacher professional standard in addition to the code of ethics as a rule of behavior of teachers as 
professional staff who refer to abilities through the process of education and training so that it is more effective. The ability of teachers to refer to rational actions to meet certain standards and specifications in the implementation of effective education (Suhana, 2012). [11] Professional competence is a factor that influences the achievement of learning and education goals in schools, which do not stand alone but are influenced by educational background, teaching experience and length of teaching (Wibowo \& Hamrin, 2012). [12] So that a teacher in carrying out obligations in a responsible and appropriate manner.

The relationship of professional competence with the results of teacher competency test is an activity carried out to evaluate, assess and measure the level of teacher basic competency in the field of study and pedagogics in the teacher content domain, in order to carry out professional duties and responsibilities as a teacher. The competency tested is the integration of pedagogical competencies into the learning process of the field of study in the classroom. The objectives include "Mapping the mastery of professional teacher competencies as a basis for consideration of the implementation of teacher professional development and development programs in the form of sustainable activities".

The results of this study further strengthen and affirm the importance of teacher professional competence related to the results of the competency test for social studies teachers at Pontianak City Junior High School. This means there is a relationship and compatibility between theory and empirical findings.

\section{Positive direct effect of work motivation (X2) on teacher competency test results} (Y)

Motivation of teacher work is an activity that is carried out consciously because there is an impulse that comes from within or comes from outside of a teacher, who is high and positive works with enthusiasm, creative, innovative, full of ideas, initiatives and has self-confidence high. Conversely, if the teacher's work motivation is low and negative, then the teacher of the person appears weak, lazy, passive, less creative, lacks initiative and tends to avoid work because he lacks high self-confidence. According to Sperling, Stanton quoted Mangkunegara (2002) motivates people to work so that people can meet stimulated needs that are oriented towards individual goals in achieving satisfaction." [13] Jones, et al (2008) say "work motivation is set of energetic forces that originate both as well as beyond individual's being, to initiate work-related behavior, and to determine its form, direction, intensity, and duration". This means more or less work motivation is an energetic set of strengths originating from both inside and outside the individual for work purposes in the form of direction, intensity, duration of work. While Pinder (2008) explain work motivation is "activity in the face of events in the world of work, career and leadership of people in the world of work". [6] Whereas Blau was quoted by Pinder (2008) said that work motivation is "to determine whether and how each contributes to job performance". Then the need for the wishes and expectations of a teacher to work supported by internal factors (physical needs, security needs, social needs, self-esteem needs and implementation needs) and external factors (salary, working conditions, work environment, work facilities, responsibility and development self). [6]

The characteristics of motivated teachers work, have the responsibility of carrying out the main tasks and functions so that the goals and expectations of the school organization are achieved, if in terms of fulfilling the needs and desires fulfilled, self-esteem is recognized, there is recognition and appreciation that the teacher gets, the creation of harmonious relationships, higher social status, supported by work facilities, facilities and infrastructure, adequate nature of the workplace environment, guarantee of job 
security, and salary in accordance with class / rank, provide opportunities for selfdevelopment through education and training as a step to increase knowledge, personality and skills. Because every teacher who works must have the knowledge, personality and skills, the benefits of training include being able to increase work productivity and creating a harmonious relationship between the principal and teachers, this can increase the motivation of work for the teacher. In line with the opinion of Siagian (2000), explaining "the benefits of training can actually lead to encouragement for employees to continue to improve their abilities, thereby increasing self-confidence, increasing job satisfaction and increasing one's recognition or ability". From the Siagian statement of teacher development through education and training, the benefits can increase the work motivation of teachers to do the best for themselves and also the school organization, so that in turn can improve the performance and productivity of teacher work, thus there is satisfaction in the teacher. ${ }^{[14]}$

The teacher has work motivation is a teacher who carries out substantial efforts to support the learning goals in school and work unity, a teacher lacks work motivation, only gives minimum effort in terms of work. Motivation of a teacher's work is not easily obtained, if the necessities of life and maintaining life are not fulfilled. Work motivation is an encouragement that comes from within the teacher and there is an encouragement that comes from outside the teacher. Work motivation originating from within the teacher is closely related to Maslow's theory of need of hierarchy. Maslow's hierarchy of needs theory relates to human needs, this theory uses a variety of teacher needs that are fulfilled so that the teacher is motivated by his work activities. Encouragement that is stimulated or not, must grow as a subject that meets their respective needs that must be achieved and at the same time as subjects who achieve results for organizational goals.
Teacher needs are arranged in a hierarchy of interests, which starts from the lowest level of need, namely physical, security, social needs, self-esteem and selfimplementation needs. This hierarchy is the most urgent need to master individual attention. Individual motivation as the first sequence of needs is determined. Physical needs are very important, but the physical needs for their own manifestations are the highest needs for each individual.

Motivation of external work (from outside), namely the condition of the work environment, supporting facilities and infrastructure, adequate compensation, good supervision, job security, self-development opportunities through education and training. According to Herbert and Gullet (2006) work motivation externally includes "salary/wages, working conditions, organizational wisdom, rewards, responsibilities, self-development, environment, and facilities". The desire to live is the need of every teacher, in order to maintain life every teacher must work hard, want to work anything, to get adequate compensation, regular work, and safe and comfortable working conditions. ${ }^{[15]}$

Principals in giving motivation to work teachers include "helping a teacher determine the effort to achieve their needs through work performance, this is not difficult if done with sincerity, not strings attached. In line with the opinion of Arep Ishak and Tanjung Hundiri (2003) said a leader can provide work motivation to his subordinates with a heart that is sincere, encouraging employees to excel". [16] The impact of teacher work motivation will create a teacher's work spirit, so that the teacher's work productivity will increase. Motivated teachers do their jobs are always encouraged to be able to complete the work well and on time according to standards, because they feel valued, and recognized by the school organization, so that teachers can increase work motivation. Teachers have high work motivation, they work of course in accordance with the standards set at the school organization, with high fighting spirit 
and supported by hard work. The teacher works happily because he feels valuable, teachers who have the motivation to work like this allow less supervision to be carried out by the principal.

Based on the results of the entire theoretical study, it can be synthesized that the teacher's work motivation is an energetic impulse that comes from within or from outside a teacher for work needs in the form of work direction, work intensity and duration of work with indicators: 1 . Direction of work behavior, 2. Work intensity, 3. Duration of work.

Teachers have a role in educating the lives of the nation's children, so the government gives special attention to teachers by implementing teacher competency tests that aim to strive to improve the quality of education for the life of the nation's children. It was even announced by the president of the Republic of Indonesia on December 4, 2004 which strengthened the role of teachers in the implementation of education. In line with the Republic of Indonesia Law number 14 of 2005 concerning teachers and lecturers. The development and development of the teaching profession is carried out for teachers who already have an educator certificate as well as for teachers who do not have an educator certificate carried out sustainably as the actualization of the teaching profession. The implementation of the competency test has been carried out simultaneously throughout Indonesia starting in 2015, in 2016.

The relationship between work motivation and teacher competency test results is an activity carried out to evaluate, assess and measure the level of motivation of teacher work in the field of study and pedagogics in the teacher's content domain, to carry out professional duties and responsibilities as a teacher. The competency tested is the integration of pedagogic competencies into the learning process of the field of study in the classroom. The goal is for example. "Information on the condition of teacher objectives as a step by the government in making policies related to material and teacher competency test strategies"

The results of this study further strengthen and provide confirmation of the importance of work motivation related to the results of the competency test for social studies teachers at Pontianak City Junior High School. This means there is a relationship and compatibility between theory and empirical findings.

\section{Positive direct effect of learning motivation (X2) on teacher competency test results $(\mathrm{Y})$}

The results of the empirical study found that learning motivation had a direct positive effect on the results of the competency test of Social Sciences teachers of Pontianak City Junior High School. Motivational teaching and learning process is needed by the teacher / student, so students who do not have the motivation to learn will not be possible to do learning activities. Therefore, the teacher plays an important role in giving attention. Teachers are motivated to learn because there is encouragement from inside and outside the teacher itself. Learning motivation is a psychological process in a teacher / student to carry out learning activities so that there is a change in understanding and insight about knowledge, personality and skills. In line with the opinion of Hamzah B. Uno (2014), it is an internal and external encouragement to students who are learning to demand knowledge and behavior changes and improve skills supported by several indicators. ${ }^{[8]}$ According to Agus Suprijono (2015) is a process of providing enthusiasm for learning, direction and persistence of behavior. ${ }^{[17]}$ According to Sardiman (2014) is a psychological factor that is nonintellectual. [18] According to Martinis Yamin (2011) is a psychic driving force from within a person to carry out learning activities and add skills and experience. Learning motivation is interpreted as an encouragement in the teacher / student to learn, do tasks, solve problems and learn 
certain competencies. In other words learning motivation is an encouragement received by someone to make a change in maturation towards a better one through a learning process that is supported from within and from someone outside. ${ }^{[19]}$

The purpose of learning motivation is trying to encourage someone to improve the quality of achievement, achieve the desired goal and obey the applicable ethics. In line with the opinion of Hikmat (2011), the purpose of learning motivation is an effort to stimulate a person to achieve more, improve quality, achieve goals, and carry out activities full of responsibility. ${ }^{[20]}$ To achieve the goals of learning motivation supported by indicators such as the desire, hope, appreciation and support of a conducive environment in line with Hamzah B.Uno, quoted by Suprijono (2014), said indicators of learning motivation include: the presence of desires, desires and learning needs, hopes and dreams - future ideas, learning awards, interesting activities in learning and learning environment. Furthermore, it can encourage someone to actively study and achieve learning goals.

The kinds of learning motivation can be divided into intrinsic motives, namely motiv that arises from within a teacher / student such as: arising learning awareness, utilizing leisure time, and discipline working on all tasks. Extrinsic motives are motiv that emerges from outside a teacher / student such as: seeing other people succeed, encouragement from co-workers, principals, work atmosphere, opportunities for achievement, rewards, salaries and benefits for teachers, desire to maintain selfesteem, desire to get good grades, the desire to be admired, the desire to compete. In line with the opinion of Thursan Hakim (2008), the types of motivation are intrinsic motivation and extrinsic motivation. Ways to cultivate learning motivation can be done by giving praise, conducting competitions, carrying out training, knowing the results and giving penalties. [21] In line with the opinion of Sardiman (2011) said the way to grow motivation to learn includes giving gifts, competing, giving numbers, giving penalties, knowing the results, interests and goals that are recognized. [18]

Teachers have a role in educating the lives of the nation's children, so the government gives special attention to teachers by implementing teacher competency tests that aim to strive to improve the quality of education for the life of the nation's children. It was even announced by the president of the Republic of Indonesia on December 4, 2004 which strengthened the role of teachers in the implementation of education. In line with the Republic of Indonesia Law number 14 of 2005 concerning teachers and lecturers. The development and development of the teaching profession is carried out for teachers who already have an educator certificate as well as for teachers who do not have an educator certificate carried out sustainably as the actualization of the teaching profession. The implementation of the competency test has been carried out simultaneously throughout Indonesia starting in 2015, in 2016.

The relationship between learning motivation and teacher competency test results is an activity carried out to evaluate, assess and measure the level of motivation of teacher work in the field of study and pedagogics in the teacher content domain, in order to carry out professional duties and responsibilities as a teacher. The competency tested is the integration of pedagogic competencies into the learning process of the field of study in the classroom. The goal is among others. "As an effort to evaluate teacher performance"

The results of this study further strengthen and provide confirmation of the importance of learning motivation related to the results of the competency test of Social Sciences teachers at Pontianak City Junior High School. This means there is a relationship and compatibility between theory and empirical findings. 
Simultaneous Direct Effect of Teacher Professional Competence (X1), Work Motivation (X2), Learning Motivation (X3) Against Competency Test Results for Social Sciences Teachers of Pontianak City Junior High School

The results of the empirical study found that the direct positive effect of teacher professional competence, work motivation, learning motivation on the results of the competency test of Social Sciences teachers at Pontianak City Junior High School. Professional competence is the main component that must be possessed by a teacher of the teacher professional standard, in addition to the code of ethics as a rule of teacher behavior as a professional staff that refers to the teacher's ability through the education process and training process so that it is more effective in supporting the learning process. Teacher's work motivation can be supported from internal teachers, namely physical needs, security, social, self-esteem and selfimplementation needs and from the external namely the conditions of the work environment, supporting facilities and infrastructure, adequate compensation, good supervision, job security, development opportunities self through education and training. The desire to live is the need of every teacher, in order to maintain life every teacher must work hard, want to work anything, to get adequate compensation, regular work, and safe and comfortable working conditions. The kinds of learning motivation can be divided into intrinsic motives, namely motive that arises from within a teacher / student such as: arising learning awareness, utilizing leisure time, and discipline working on all tasks. Extrinsic motives are motive that emerges from outside a teacher / student such as: seeing other people succeed, encouragement from co-workers, principals, work atmosphere, opportunities for achievement, rewards, salaries and benefits for teachers, desire to maintain self-esteem, desire to get good grades, the desire to be admired, the desire to compete. In line with the opinion of Thursan Hakim (2008), the types of motivation are intrinsic motivation and extrinsic motivation. Ways to cultivate learning motivation can be done by giving praise, conducting competitions, carrying out training, knowing the results and giving penalties. [21] In line with the opinion of Sardiman (2011) said the way to grow motivation to learn includes giving gifts, competing, giving numbers, giving penalties, knowing the results, interests and goals that are recognized. ${ }^{[18]}$ Teachers have a role in educating the lives of the nation's children, so the government gives special attention to teachers by implementing teacher competency tests that aim to strive to improve the quality of education for the life of the nation's children. It was even announced by the president of the Republic of Indonesia on December 4, 2004 which strengthened the role of teachers in the implementation of education. In line with the Republic of Indonesia Law number 14 of 2005 concerning teachers and lecturers. The development and development of the teaching profession is carried out for teachers who already have an educator certificate as well as for teachers who do not have an educator certificate carried out sustainably as the actualization of the teaching profession. The implementation of the competency test has been carried out simultaneously throughout Indonesia starting in 2015, in 2016.

The relationship of teacher professional competence, work motivation and learning motivation with the results of teacher competency test is an activity carried out to evaluate, assess and measure the level of teacher competence in the field of study and pedagogics in the teacher content domain, to carry out professional duties and responsibilities as a teacher. The competency tested is the integration of pedagogic competencies into the learning process of the field of study in the classroom. The goal, including "As a means of control the implementation of teacher performance assessment". 
Aminuyati et.al. The influence of professional competence, work motivation \& learning motivation on the competency test results of social studies teachers.

The results of this study further strengthen and provide confirmation of the importance of teacher professional competence, learning motivation and work motivation related to the results of the competency test of the Pontinak City Junior High School IPS teacher. This means there is a relationship and compatibility between theory and empirical findings.

\section{CONCLUSIONS}

Based on the results of the research and discussion discussed earlier, it can be summarized as follows: (1) Professional competency of teachers has a direct positive effect on the results of the competency test of Social Studies teachers of Pontianak City Junior High School; (2) Work motivation has a positive direct effect on the results of the competency test for social studies teachers at Pontianak City Junior High School; (3) Motivation for learning has a positive direct effect on the results of the competency test for social studies teachers at Pontianak City Junior High School; (4) Professional teacher competency, work motivation, learning motivation simultaneously have a positive direct effect on the results of the competency test of Social Sciences teachers at Pontianak City Junior High School. Teachers have a role in educating the lives of the nation's children, so the government gives special attention to teachers by implementing teacher competency tests that aim to strive to improve the quality of education for the life of the nation's children. It was even announced by the president of the Republic of Indonesia on December 4, 2004 which strengthened the role of teachers in the implementation of education. In line with the Republic of Indonesia Law number 14 of 2005 concerning teachers and lecturers. The development and development of the teaching profession is carried out for teachers who already have an educator certificate as well as for teachers who do not have an educator certificate carried out sustainably as the actualization of the teaching profession. The implementation of the competency test has been carried out simultaneously throughout Indonesia starting in 2015, in 2016.

\section{Acknowledgement: None}

\section{Conflict of Interest: None}

\section{Source of Funding: None}

\section{REFERENCES}

1. Republic of Indonesia Law Number 20 of 2003 concerning the National Education System

2. Becker G.S. Human Capital, A Theoritical and Empirical Analysis with Special Reference to Education. Chicago: University of Chicago Press.

3. Tilaar HR, 2000, Paradigma Baru Pendidikan Nasional, Jakarta: Reneka Cipta

4. Aminuyati, 2016, Strategi Belajar Mengajar IPS, Pontianak: FKIP Univrsitas Tanjungpura Pontianak, 1993.

5. Jones, Gareth R. \& George, Jennifer M., Contemporary Management (Fifth Edition). USA: McGRAWhill-International, 2008.

6. Pinder, C., C. (2008). Work motivation in organizational behavior. New York: Psychology Press.

7. Maslow, A.H., Motivation and Personality. Rajawali, Jakarta, 2006.

8. Hamzah. B. Uno, Teori Motivasi dan Pengukurannya. Jakarta: Bumi Aksara, 2014.

9. Undang-Undang Republik Indonesia Nomor 14 Tahun 2005 Tentang Guru Dan Dosen

10. Becker, G.S., Human Capital : a theoretical and empirical analysis, with special reference to education 3rd edition. London : The University of Chicago Press, Ltd., 1993.

11. Suhana, C., Konsep Strategi pembelajaran, Bandung: Refika Aditama, 2014,

12. Wibowo. Agus dan Hermin, Manjemen Perubahan. Jakarta: PT. Raja Grafindo Persada, 2012.

13. Mangkunegara, Anwar Prabu, Manajemen Sumber Daya Manusia Perusahaan. Bandung: PT. Remaja Rosdakarya, 2002.

14. Siagian, Sondang P., Manjemen Abad 21. Jakarta: Bumi Aksara, 2008.

15. Hicks G Herbert dan G Ray Gullet, Organisasi Teori dan Tingkah Laku, Alih 
Aminuyati et.al. The influence of professional competence, work motivation \& learning motivation on the competency test results of social studies teachers.

Bahasa oleh G.Kartasapoetra dan A.G Kartasapoetra, Jakarta: Bumi Aksara, 2006.

16. Iskak, Arep, \& Tanjung Hendiri, Manajemen Motivasi,Jakarta: PT Gramedia Widiasarana, 2003.

17. Agus Suprijono, Cooperative learning, Yogyakarta: Pustaka Pelajar, 2015.

18. Sardiman A.M., Interaksi dan Motivasi Belajar Mengajar, Jakarta: PT Raja Grafindo Persada, 2015.

19. Martinis Yamin, Paradigma Baru Pembelajaran, Jakarta: Gaung Persada, 2011.
20. Hikmat, Manajemen Pendidikan, Bandung: CV Pustaka Setia, 2011.

21. Thursan Hakim, Belajar Secara Efektif, Jakarta: Puspa Swara, 2008

How to cite this article: Aminuyati; Achmadi; Okiana. The influence of professional competence, work motivation \& learning motivation on the competency test results of social studies teachers. International Journal of Research and Review. 2021; 8(12): 83-93. DOI: https://doi.org/10.52403/ijrr.20211212 